\title{
RENEWABLE ENERGY
}

COLUMBIA UNIVERSITY

EARTH INSTITUTE SUSTAINABILITY PRIMERS 


\section{COLUMBIA UNIVERSITY \\ EARTH INSTITUTE SUSTAINABILITY PRIMERS}

The Earth Institute (EI) at Columbia University is dedicated to innovative research and education to support the emerging field of sustainability. The Columbia University Earth Institute Sustainability Primers series, published in collaboration with Columbia University Press, offers short, solutions-oriented texts for teachers and professionals that open up enlightened conversations and inform important policy debates about how to use natural science, social science, resource management, and economics to solve some of our planet's most pressing concerns, from climate change to food security. The EI primers are brief and provocative, intended to inform and inspire a new, more sustainable generation. 


\title{
RENEWABLE ENERGY
}

\author{
A PRIMER FOR THE
}

TWENTY-FIRST CENTURY

\section{BRUCE USHER}




$$
\begin{aligned}
& \text { Columbia University Press } \\
& \text { Publishers Since } 1893 \\
& \text { New York Chichester, West Sussex } \\
& \text { cup.columbia.edu } \\
& \text { Copyright @ 20I9 Bruce Usher } \\
& \text { All rights reserved }
\end{aligned}
$$

Library of Congress Cataloging-in-Publication Data

Names: Usher, Bruce, author.

Title: Renewable energy : a primer for the twenty-first century /

Bruce Usher.

Description: New York : Columbia University Press, [2019] |

Series: Columbia University earth institute sustainability primers |

Includes bibliographical references and index.

Identifiers: LCCN 20I8024274 | ISBN 978023II87848 (cloth : alk. paper) |

ISBN 9780231187855 (pbk. : alk. paper) | ISBN 9780231547529 (e-book)

Subjects: LCSH: Renewable energy sources.

Classification: LCC TJ808 .U84 2019 | DDC 333.79/4—dc23

LC record available at https://lccn.loc.gov/20I8024274

Columbia University Press books are printed on permanent and durable acid-free paper.

Printed in the United States of America

Cover design: Julia Kushnirsky

Cover image: (C) Benjamin Van Der Spek / EyeEm / Getty Images 